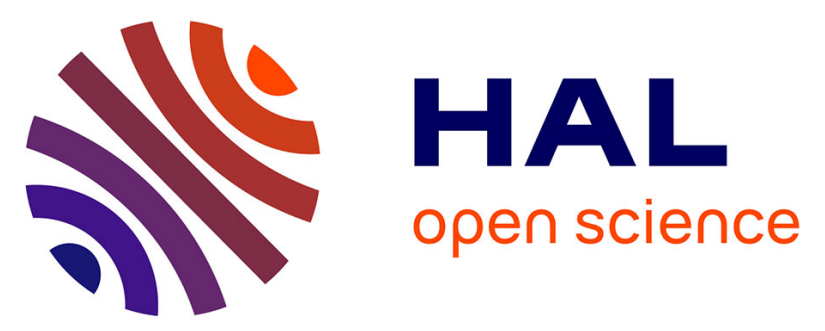

\title{
Impact of Environmental Radiation on the Health and Reproductive Status of Fish from Chernobyl
}

Adélaïde Lerebours, Dmitri Gudkov, Liubov Nagorskaya, Alexander Kaglyan, Viktor Rizewski, Andrey Leshchenko, Elizabeth H Bailey, Adil Bakir, Svetlana Ovsyanikova, Gennady Laptev, et al.

\section{To cite this version:}

Adélaïde Lerebours, Dmitri Gudkov, Liubov Nagorskaya, Alexander Kaglyan, Viktor Rizewski, et al.. Impact of Environmental Radiation on the Health and Reproductive Status of Fish from Chernobyl. Environmental Science and Technology, 2018, 52 (16), pp.9442-9450. 10.1021/acs.est.8b02378 . hal01978293

\section{HAL Id: hal-01978293 https://hal.science/hal-01978293}

Submitted on 11 Jan 2019

HAL is a multi-disciplinary open access archive for the deposit and dissemination of scientific research documents, whether they are published or not. The documents may come from teaching and research institutions in France or abroad, or from public or private research centers.
L'archive ouverte pluridisciplinaire HAL, est destinée au dépôt et à la diffusion de documents scientifiques de niveau recherche, publiés ou non, émanant des établissements d'enseignement et de recherche français ou étrangers, des laboratoires publics ou privés. 


\section{Impact of Environmental Radiation on the Health and Reproductive Status of Fish from Chernobyl}

Adélaïde Lerebours, ${ }^{*},+\ddagger \odot$ Dmitri Gudkov, ${ }^{\S}$ Liubov Nagorskaya, " Alexander Kaglyan, ${ }^{\S}$ Viktor Rizewski, Andrey Leshchenko," Elizabeth H. Bailey, ${ }^{\perp}$ Adil Bakir, ${ }^{\dagger}$ Svetlana Ovsyanikova, ${ }^{\dagger}$ Gennady Laptev, ${ }^{\nabla}$ and Jim T. Smith ${ }^{\dagger}$

${ }^{\dagger}$ School of Earth and Environmental Sciences, University of Portsmouth, Portsmouth, PO1 3QL, United Kingdom

${ }^{\ddagger}$ School of Biological Sciences, University of Portsmouth, Portsmouth, PO1 2DY, United Kingdom

${ }^{\S}$ Institute of Hydrobiology of the National Academy of Sciences of Ukraine, Kiev, UA-04210, Ukraine

"Applied Science Center for Bioresources of the National Academy of Sciences of Belarus, Minsk, 220072, Belarus

${ }^{\perp}$ School of Biosciences, University of Nottingham, Loughborough, LE12 5RD, United Kingdom

\#Belarussian State University, Faculty of Chemistry, Research Laboratory of Radiochemistry, Minsk, 220030, Belarus

${ }^{\nabla}$ Ukrainian HydroMeteorological Institute, Kiev, 03028, Ukraine

Supporting Information

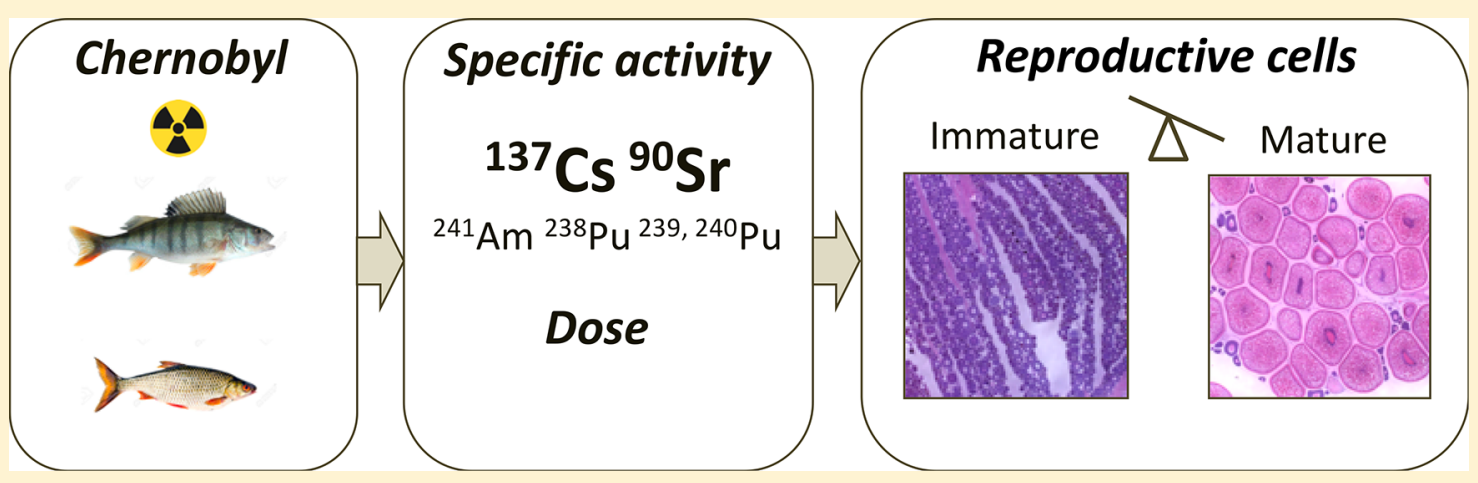

ABSTRACT: Aquatic organisms at Chernobyl have now been chronically exposed to environmental radiation for three decades. The biological effects of acute exposure to radiation are relatively well documented, but much less is known about the long-term effects of chronic exposure of organisms in their natural environment. Highly exposed fish in freshwater systems at Chernobyl showed morphological changes in their reproductive system in the years after the accident. However, the relatively limited scope of past studies did not allow robust conclusions to be drawn. Moreover, the level of the radiation dose at which significant effects on wildlife occur is still under debate. In the most comprehensive evaluation of the effects of chronic radiation on wild fish populations to date, the present study measures specific activities of ${ }^{137} \mathrm{Cs},{ }^{90} \mathrm{Sr}$, and transuranium elements $\left({ }^{238} \mathrm{Pu}\right.$, ${ }^{239,240} \mathrm{Pu}$, and $\left.{ }^{241} \mathrm{Am}\right)$, index conditions, distribution and size of oocytes, as well as environmental and biological confounding factors in two fish species perch (Perca fluviatilis) and roach (Rutilus rutilus) from seven lakes. In addition, relative species abundance was examined. The results showed that both fish species are, perhaps surprisingly, in good general physiological and reproductive health. Perch, however, appeared to be more sensitive to radiation than roach: in the most contaminated lakes, a delay of the maturation of the gonads and the presence of several undeveloped phenotypes were evident only for perch and not for roach.

\section{INTRODUCTION}

Wildlife has been chronically exposed to environmental radiation from the Chernobyl accident for the past 30 years. The biological effects of acute exposure to radiation in laboratory settings have been relatively well studied (Frederica radiation database: www.frederica-online.org ${ }^{1}$ ), but relatively little is known about the effect of long-term chronic exposure of organisms in the natural environment. The fate of wildlife remaining in the Chernobyl Exclusion Zone (CEZ) is under debate, and controversy continues on the dose rate at which significant environmental impacts occur. Previous studies found no evidence of effects of radiation on aquatic macroinvertebrate or mammal populations ${ }^{2,3}$ whereas others found reduced abundance of insect, spider, bird, and mammal populations $^{4-6}$ at Chernobyl and Fukushima. Environmental

Received: $\quad$ May 4, 2018

Revised: July 19, 2018

Accepted: July 20, 2018

Published: July 20, 2018 


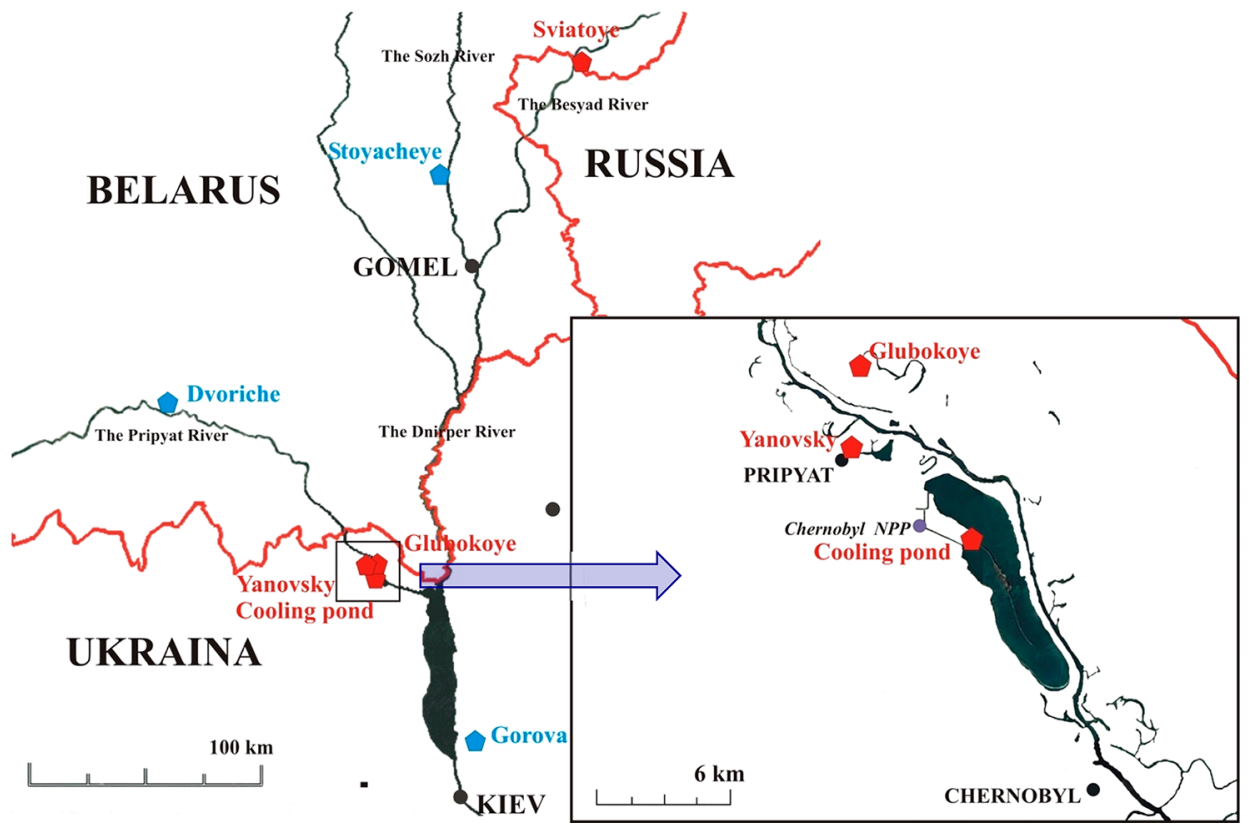

Figure 1. Map showing the sampling sites in the Mogilev (Svyatoye Lake (M)) and Gomel (Stoyacheye and Dvoriche lakes (L)) regions of Belarus, in the CEZ (Glubokoye Lake, Yanovsky Lake, and Cooling Pond $(\mathrm{H})$ ) and in the eastern region of Kiev in Ukraine (Gorova lake (L)). Map modified from Google Earth.

studies on the long-term effects of radionuclide contamination at Chernobyl are of crucial importance for refining the environmental protection regulations, underpinning the public and political debate on risks of exposure to ionizing radiation and predicting the long-term impact on the environment of the more recent nuclear accident at Fukushima.

Fish are considered to be the most radiosensitive aquatic organisms ${ }^{7}$ and have been highly exposed in freshwater systems at Chernobyl since the accident on the 26th of April 1986. At Fukushima, both freshwater and marine fish have been exposed since the March 2011 accident. At Chernobyl, the highest dose rate to fish after the accident was estimated to be $400 \mu \mathrm{Gy} / \mathrm{h}^{8}{ }^{8}$ Dose rates rapidly declined after the accident due to decay of short-lived isotopes and decreased bioavailability of ${ }^{137} \mathrm{Cs}$ and its accumulation to bottom sediment. ${ }^{9}$ In the first month after the accident, the ${ }^{137} \mathrm{Cs}$ activity concentration were the highest in prey fish, whereas a few years later, the highest concentrations were recorded in predatory fish such as perch and pike. ${ }^{10}$ Bioaccumulation of ${ }^{137} \mathrm{Cs}$ in fish muscles increases with size in silver carp, catfish, and pike-perch from Cooling Pond ${ }^{11}$ and the trophic level in the foodweb. ${ }^{12}{ }^{90} \mathrm{Sr}$ (a $\beta$ emitter) and ${ }^{137} \mathrm{Cs}$ (a $\beta$ and $\gamma$ emitter) are the main radionuclides of concern due to their long radioactive half-life (28 and 30 years, respectively), though transuranium elements ${ }^{238} \mathrm{Pu}(\alpha$ emitter $),{ }^{239,240} \mathrm{Pu} \quad(\alpha$ emitters), and ${ }^{241} \mathrm{Am}$ ( $\alpha$ and low energy $\gamma$ emitter) of radioactive half-life $88,24000,6500$, and 432 years also need to be considered.

In fish from lakes contaminated by the Chernobyl accident, morphological changes were most frequently recorded in the reproductive system. The occurrence of anomalies apparently remained high after several generations postaccident in different fish species ${ }^{13,14}$ despite the continuing decrease of ${ }^{137}$ Cs specific activity. ${ }^{15}$ Only one study in the literature relates the biological effects of radiation on fish after the Fukushima Dai-ichi NPP accident. ${ }^{16}$ The author found a higher number of melano-macrophages centers in different tissues and a lower number of leucocytes in exposed carps from Fukushima ponds but the causative link with radiation has yet to be confirmed due to the low number of lakes studied. ${ }^{16}$ Ionizing radiation induces DNA damage but only a few studies have investigated DNA damage in relation to long-term exposure to radionuclides in the environment. A study led on catfish from Cooling Pond did not find any positive correlation between radiation exposure level and chromosomal damage. ${ }^{17}$ However, these two studies were restricted to a small number of lakes; therefore, no robust quantification of the observed effects could be achieved.

The present study is, to our knowledge, the largest study of radiation effects on fish in the natural environment. It assesses whether three decades of direct and multigenerational exposure to radiation from the Chernobyl accident significantly affect the physiology of freshwater fishes. For this purpose, perch (Perca fluviatilis) and roach (Rutilus rutilus) were collected from seven lakes exposed to a gradient of contamination and located inside and outside the CEZ.

It was hypothesized that three decades of exposure to radiation was sufficient to negatively affect the general health and reproductive status of natural populations of perch and roach.

\section{METHODS}

Fish Collection. For the health and reproductive status assessment 124 perch and 82 roach (Supporting Information (SI) Table S1) of similar weight (Wb) and total length (Lt) were collected in September 2014 (perch: $\mathrm{Wb}=84 \pm 25 \mathrm{~g}$, Lt $=19 \pm 2 \mathrm{~cm}$. Roach: $\mathrm{Wb}=92 \pm 20 \mathrm{~g}, \mathrm{Lt}=20 \pm 1 \mathrm{~cm}$ ) (from seven lakes in Belarus and Ukraine) and in September 2015 (Perch: $\mathrm{Wb}=77 \pm 27 \mathrm{~g}, \mathrm{Lt}=18 \pm 2 \mathrm{~cm}$. Roach: $\mathrm{Wb}=91 \pm$ $27 \mathrm{~g}, \mathrm{Lt}=20 \pm 2 \mathrm{~cm}$ ) from the four lakes in Ukraine (Figure 1) using three gill nets of $20 \mathrm{~m}$ length and $21 \mathrm{~mm}$ mesh size to ensure the capture of homogeneous groups of mature fish; 38 perch and 60 roach were also collected in March 2015 just before spawning. The relative abundance of fish species in each 
lake was evaluated by recording the number of fish caught for each species during an additional sampling session in June 2015. Perch and roach were carefully removed from the nets and kept alive into tanks containing aerated water. Fish fell unconscious by a blow to the head and were then killed by performing a concussion of the brain to limit as much as possible the suffering as recommended by the UK Home Office procedure (Animals Scientific Procedures Act, $1986^{18}$ ). Scales were sampled for age determination. The body weight, total length, and presence of external signs of disease and macroscopic tumors were noted for each fish using methodology specified by ICES. ${ }^{19}$ The presence of liver parasites was recorded. The Fulton condition index, $K$, the hepatosomatic index, HSI, and the gonadosomatic index, GSI, were determined as described in the SI.

Sampling Sites. Lake description. Seven lakes situated in Belarus and Ukraine (Figure 1) were selected according to their hydrological properties (Table S2) and the long-term exposure to a gradient of radiation doses (Table S2). The lakes are situated at distances from 1.5 to $225 \mathrm{~km}$ of the Chernobyl NPP. Glubokoye, Yanovsky lakes and Cooling Pond are the high $(\mathrm{H})$ contaminated lakes, Svyatoye Lake is a medium (M) contaminated lake, and Stoyacheye, Dvoriche and Gorova lakes are the low $(\mathrm{L})$ contaminated lakes.

Water Chemistry. Multiple chemical parameters were measured to assess the presence of potential confounding abiotic factors in each lake during all sampling sessions.

The $\mathrm{pH}$, temperature, dissolved oxygen (DO), and conductivity $(\mu \mathrm{S} / \mathrm{cm})$ were measured (Table S2B). Water samples were collected at three different locations within the surface waters of each lake for elemental $(\mathrm{Na}, \mathrm{Mg}, \mathrm{S}, \mathrm{K}, \mathrm{Ca}, \mathrm{As}$, $\mathrm{Sr}, \mathrm{Cd}, \mathrm{Cs}, \mathrm{Pb}$, and $\mathrm{U})$ and nutrient $\left(\mathrm{NO}_{3}{ }^{-}, \mathrm{NO}_{2}{ }^{-}\right.$, and $\left.\mathrm{PO}_{4}{ }^{3-}\right)$ analysis in September 2014 and 2015. The methods used are described in the SI.

Activity Measurements of ${ }^{137} \mathrm{Cs},{ }^{90} \mathrm{Sr},{ }^{238} \mathrm{Pu},{ }^{239,240} \mathrm{Pu}$, and ${ }^{241} \mathrm{Am}$. The activity concentration of ${ }^{137} \mathrm{Cs}$ was measured on the whole body of five additional fish collected in September 2014 from each of the seven lakes using a $\gamma$ spectrometer with lithium-drifted germanium detector (DGDK-100, Russia, detection limit: $0.6 \mathrm{~Bq}$ ). The activity concentration of ${ }^{90} \mathrm{Sr}$ was measured on the whole body of five fish from Glubokoye Lake $(\mathrm{H})$, Cooling Pond $(\mathrm{H})$, and Yanovsky $(\mathrm{H})$ Lake using a radiochemical oxalate procedure with measurement of the ${ }^{90} \mathrm{Y}$ radiochemistry, as daughter product, using the $\alpha, \beta$ radiometer (UMF-2000, Russia, detection limit on the $\beta$ channel: $0.01 \mathrm{~Bq}$ ).

The activity concentration of ${ }^{238} \mathrm{Pu},{ }^{239,240} \mathrm{Pu}$, and ${ }^{241} \mathrm{Am}$ were measured in liver and muscle (and skin) of 3 to 5 additional fish from Glubokoye Lake $(\mathrm{H})$, Cooling Pond $(\mathrm{H})$, and Yanovsky Lake $(\mathrm{H})$ as these radionuclides were mainly deposited in the vicinity of the nuclear power plant after the accident. The measurements were performed using radiochemical extraction chromatography separation on Sr-Resin and TRU-Resin (Eichrom, USA) followed by alpha-spectrometry on $\alpha 8$ instrument (BSI, Latvia, detection limit on the $\alpha$ channel: $0.001 \mathrm{~Bq}$ ). The activity concentration of ${ }^{241} \mathrm{Am}$ linked to $\gamma$ emissions was measured using a $\gamma$ spectrometer with high purity germanium detectors GMX-40 (AMETEC, Ortec, USA).

Uncertainties of ${ }^{137} \mathrm{Cs},{ }^{90} \mathrm{Sr}$, and transuranium activity measurements did not exceed 20\%, $15 \%$, and $25 \%$, respectively, at a confidence interval of 0.95 .
Dose Calculation. External doses were calculated from ${ }^{137} \mathrm{Cs} \gamma$ radiation, as this is the dominant contributor to external dose while external exposure to ${ }^{90} \mathrm{Sr}$ and ${ }^{137} \mathrm{Cs} \beta$ radiation are minor as the water provides effective shielding for external $\beta$ particles. The ${ }^{137} \mathrm{Cs}$ external doses were estimated using the calculated radioactivity concentration in sediment and external dose coefficient using the ERICA tool. ${ }^{20}$ The average activity concentration in surface sediments was estimated from the decay-corrected deposition of ${ }^{137} \mathrm{Cs}(\mathrm{Bq} /$ $\mathrm{m}^{2}$ ) to each of the lakes and assuming that the majority of the ${ }^{137} \mathrm{Cs}$ is within the $15 \mathrm{~cm}$ surface sediment, ${ }^{9}$ and that the sediment density is $1300 \mathrm{~kg} / \mathrm{m}^{3}$. External dose rates were calculated using the dose conversion factor: $1.45 \times 10^{-4} \mu \mathrm{Gy} /$ $\mathrm{h}$ per $\mathrm{Bq} / \mathrm{kg} \mathrm{ww}{ }^{20}$ considering an occupation factor of 0.5 at the sediment surface. Internal doses were calculated for ${ }^{137} \mathrm{Cs}$ in perch and roach from all the lakes while internal doses from ${ }^{90} \mathrm{Sr},{ }^{241} \mathrm{Am},{ }^{238} \mathrm{Pu}$, and ${ }^{239,240} \mathrm{Pu}$ were calculated in fish collected in the vicinity of the NPP (Glubkoye $(\mathrm{H})$, Yanovsky $(\mathrm{H})$, and Cooling Pond $(\mathrm{H})) ;{ }^{90} \mathrm{Sr},{ }^{241} \mathrm{Am},{ }^{238} \mathrm{Pu}$, and ${ }^{239,240} \mathrm{Pu}$ activity concentrations are not significant in the lakes outside the near zone. ${ }^{9}$ For the calculation of ${ }^{137} \mathrm{Cs}$ internal dose, the dose conversion coefficient factor, $4.32 \times 10^{-6} \mathrm{mGy} / \mathrm{d}$ per $\mathrm{Bq} /$ $\mathrm{kg}^{20}$, and the ${ }^{137} \mathrm{Cs}$ specific activity were used. For the calculation of the ${ }^{90} \mathrm{Sr}$ internal dose, the dose conversion coefficient factor, $1.51 \times 10^{-5} \mathrm{mGy} / \mathrm{d}$ per $\mathrm{Bq} / \mathrm{kg}^{20}$, and the ${ }^{90} \mathrm{Sr}$ specific activity were used. For the calculation of ${ }^{241} \mathrm{Am}$, ${ }^{238} \mathrm{Pu}$, and ${ }^{239,240} \mathrm{Pu}$ internal dose, the dose conversion coefficient factors, $7.61 \times 10^{-5}, 7.61 \times 10^{-5}, 7.2 \times 10^{-5}$ $\mathrm{mGy} / \mathrm{d}$ per $\mathrm{Bq} / \mathrm{kg}^{20}$, and the specific activities were used for ${ }^{241} \mathrm{Am},{ }^{238} \mathrm{Pu}$, and ${ }^{239,240} \mathrm{Pu}$, respectively.

Micronucleus Test. The loss of genetic material from the nucleus of blood cells (erythrocytes) was investigated by applying the micronucleus test to five fish that were also used for histological analyses using a standard procedure as described in The SI.

Histological Analyses. A standardized cross section of liver and gonad were fixed and processed according to standard protocols described in the SI. The liver sections were examined for microscopic pretumor and tumor lesions according to BEQUALM and ICES criteria, ${ }^{18}$ and lesions associated with nuclear and cellular polymorphism, cell death, inflammation, and regeneration. For the female gonad sections, the distribution of immature or mature oocytes was determined by counting the number of perinuclear and cortical alveolar oocytes in a defined surface area at magnification 10 using a microscope (Zeiss axiozoom), and the relative frequency of a germ cell stage was calculated as follows: (number of oocytes at a given stage/total number of oocytes $) \times 100$. Oocyte surface was measured using Zen Pro software.

Statistical Analyses. Statistical analyses were performed using $\mathrm{R}$ version 3.1.2. After satisfying the assumptions of the normal distribution of the residuals, generalized linear models were used. If the normality of the residuals was not respected, a Kruskal-Wallis rank test was applied. When significant, a Wilcoxon rank test and a Bonferroni correction of the $\alpha$ error were performed. Pearson correlation tests were performed. Further details are provided in SI.

\section{RESULTS}

Water Chemistry. Electrical conductivity varied from 120 to $318 \mu \mathrm{S} / \mathrm{cm}$ and the $\mathrm{pH}$ from 6.3 to 8.6 at the water surface of the lakes. Dissolved oxygen varied from 48 to $125 \%$ and the 

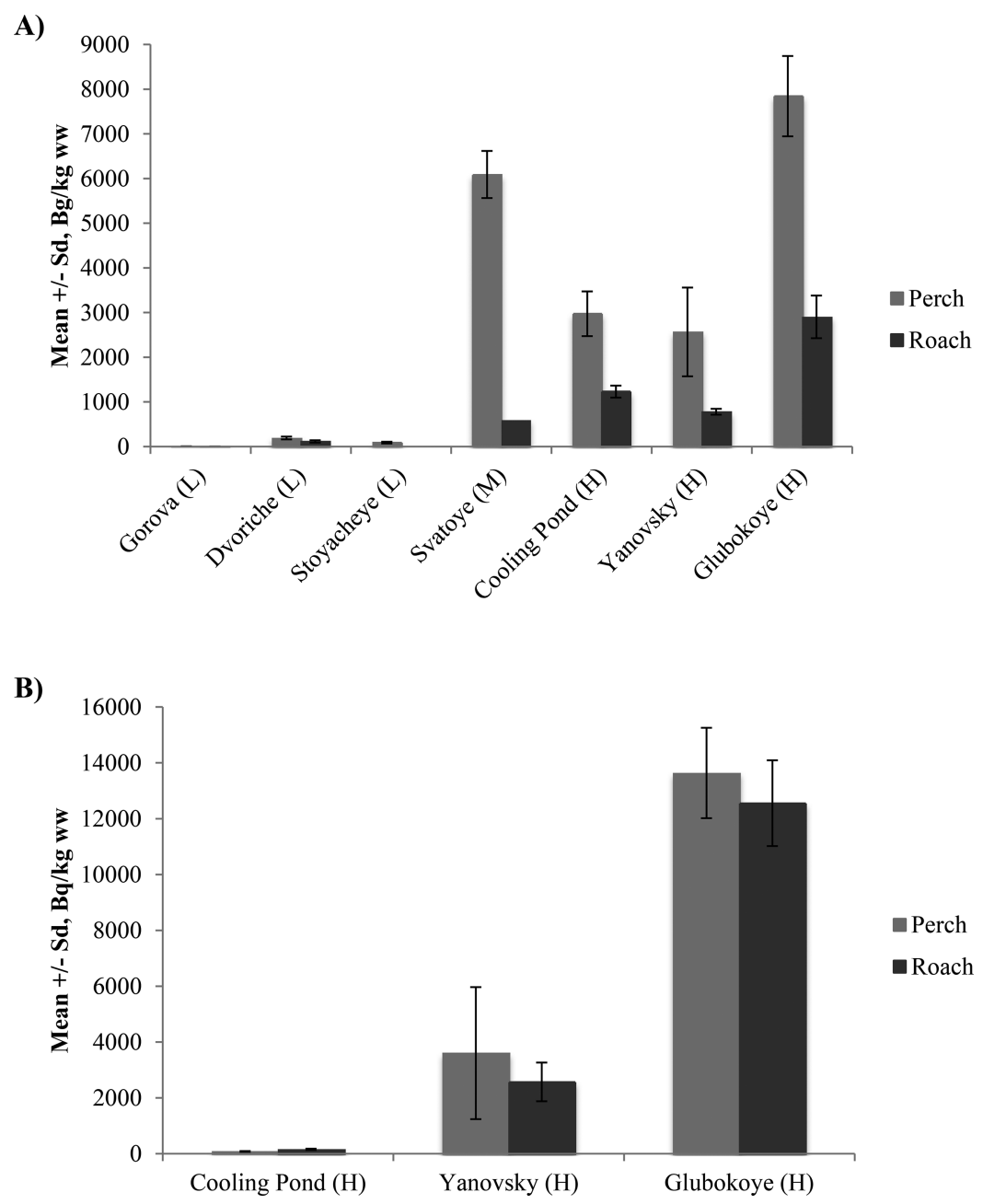

Figure 2. Mean activity concentration of ${ }^{137} \mathrm{Cs}(\mathrm{A})$ and ${ }^{90} \mathrm{Sr}(\mathrm{B})$ in perch and roach $(n=5$, mean $\pm \mathrm{Sd}, \mathrm{Bq} / \mathrm{kg}$, w.w.) collected in and outside the CEZ. Analysis found a significantly higher ${ }^{137} \mathrm{Cs}$ activity concentration in perch than in roach (A), but no difference of ${ }^{90} \mathrm{Sr}$ activity concentration between the two species (B).

temperature from 15.6 to $20.1{ }^{\circ} \mathrm{C}$ at the water surface of the lakes (Table S2). Surface water concentrations of $\mathrm{NO}_{3}{ }^{-}$and $\mathrm{NO}_{2}{ }^{-}$varied from 49 to $259 \mu \mathrm{g} / \mathrm{L}$ and from 1.5 to $11.9 \mu \mathrm{g} / \mathrm{L}$, respectively, across the lakes (Table S2). Surface water concentrations of $\mathrm{PO}_{4}{ }^{3-}$ varied from 1.4 to $15 \mu \mathrm{g} / \mathrm{L}$ across the lakes (Table S2). Concentrations of toxic trace elements (As, $\mathrm{Cd}, \mathrm{Pb}$, and $\mathrm{U}$ ) were low $(<1 \mu \mathrm{g} / \mathrm{L})$ in surface waters of all lakes (Tables S3).

Full results are presented in SI.

Significant Contamination of Fish from the CEZ with ${ }^{137} \mathrm{Cs},{ }^{90} \mathrm{Sr},{ }^{241} \mathrm{Am},{ }^{239,240} \mathrm{Pu}$, and ${ }^{238} \mathrm{Pu}$. Thirty years after the Chernobyl accident, fish from the lakes located in the CEZ and in Belarus (Svyatoye $(\mathrm{M})$ ) are still significantly contaminated with ${ }^{137} \mathrm{Cs}(p<0.001)$ (Figure $\left.2 \mathrm{~A}\right)$. Perch from Glubokoye $(\mathrm{H})$ and Svyatoye $(\mathrm{M})$ lakes have the highest activity concentrations of ${ }^{137} \mathrm{Cs}$, reaching $7844 \pm 899$ and 6090 $\pm 526 \mathrm{~Bq} / \mathrm{kg}$ w.w. (wet weight), respectively. Perch from Yanovsky $(\mathrm{H})$ and Cooling Pond $(\mathrm{H})$ are contaminated to a lesser extent with ${ }^{137}$ Cs levels reaching $2567 \pm 993$ and $2974 \pm$ $501 \mathrm{~Bq} / \mathrm{kg}$ w.w., respectively. Perch from Dvoriche (L), Stoyacheye (L), and Gorova (L) lakes contained much lower ${ }^{137}$ Cs levels: $193 \pm 31,88 \pm 20$, and $4 \pm 1 \mathrm{~Bq} / \mathrm{kg}$ w.w., respectively (Figure $2 \mathrm{~A}$ ). The activity concentration of ${ }^{137} \mathrm{Cs}$ is higher in perch than in roach $(p<0.001)$ and by a factor $2-3$ for the CEZ lakes (Figure 2A).

Fish from the CEZ are still significantly contaminated with ${ }^{90} \mathrm{Sr}$ (Figure 2B). Concentration levels for both species significantly differ across sites $(p<0.001)$ and reached, for perch and roach, respectively, $13636 \pm 1618$ and $12556 \pm$ $1536 \mathrm{~Bq} / \mathrm{kg}$ w.w. in Glubokoye $(\mathrm{H})$ lake, $3603 \pm 2364$ and $2572 \pm 694 \mathrm{~Bq} / \mathrm{kg}$ w.w. in Yanovsky $(\mathrm{H})$ lake, and $79 \pm 16$ and $157 \pm 23 \mathrm{~Bq} / \mathrm{kg}$ w.w. in Cooling Pond $(\mathrm{H})$ (Figure 2B). These are whole fish activity concentrations, most of the ${ }^{90} \mathrm{Sr}$ is found in bony tissues. ${ }^{21}$ There was no significant difference in ${ }^{90} \mathrm{Sr}$ activity concentrations between perch and roach $(p=0.34$ $>0.05$ ) (Figure 2B).

Fish from the CEZ are significantly contaminated with ${ }^{241} \mathrm{Am}{ }^{239,240} \mathrm{Pu}$, and ${ }^{238} \mathrm{Pu}$ (Figure S1, Table S4). Concentration levels in liver were significantly higher than in muscle for both species $(p<0.001)$. For instance, ${ }^{241} \mathrm{Am}$ concentration levels in liver were 7 to 11 times higher than in muscle. Concentration levels of ${ }^{241} \mathrm{Am},{ }^{239,240} \mathrm{Pu}$, and ${ }^{238} \mathrm{Pu}$ in liver and muscle of perch from Glubokoye $(\mathrm{H})$ were significantly higher than in perch from Yanovsky Lake and Cooling Pond $(p<$ 0.05) (Figure S1, Table S4). Concentration levels of ${ }^{241} \mathrm{Am}$ ${ }^{239,240} \mathrm{Pu}$, and ${ }^{238} \mathrm{Pu}$ in liver and muscle of roach did not vary 
significantly across the lakes $(p>0.05)$ (Figure S1). Further details are provided in the SI.

Dose Rate to Fish. The ${ }^{90} \mathrm{Sr}$ internal dose rates (whole body average) varied from 0.1 (Cooling Pond $(\mathrm{H})$ ) to 7.7 (Glubokoye $(\mathrm{H})) \mu \mathrm{Gy} / \mathrm{h}$ in roach and from 0 (Cooling Pond

Table 1. Table Showing the Calculated ${ }^{90} \mathrm{Sr}$ and ${ }^{137} \mathrm{Cs}$ Internal Dose Rates, ${ }^{137}$ Cs External Dose Rates and the Total Dose Rates. All Doses Were Corrected to 2015

\begin{tabular}{|c|c|c|c|c|c|c|c|}
\hline \multirow[b]{2}{*}{ lake } & \multicolumn{2}{|c|}{$\begin{array}{c}{ }^{137} \text { Cs internal } \\
\text { dose rate } \\
(\mu \mathrm{Gy} / \mathrm{h}) \\
2015\end{array}$} & \multicolumn{2}{|c|}{$\begin{array}{c}{ }^{90} \mathrm{Sr} \text { internal } \\
\text { dose rate } \\
(\mu \mathrm{Gy} / \mathrm{h}) \\
2015\end{array}$} & \multirow{2}{*}{$\begin{array}{c}{ }^{137} \mathrm{Cs} \\
\text { external } \\
\text { dose rate } \\
(\mu \mathrm{Gy} / \mathrm{h}) \\
2015\end{array}$} & \multicolumn{2}{|c|}{$\begin{array}{l}\text { total dose rate } \\
(\mu \mathrm{Gy} / \mathrm{h}) 2015\end{array}$} \\
\hline & roach & perch & roach & perch & & roach & perch \\
\hline $\begin{array}{l}\text { Glubokoye } \\
(\mathrm{H})\end{array}$ & 0.5 & 1.4 & 7.7 & 8.4 & 5.9 & 14.1 & 15.7 \\
\hline $\begin{array}{l}\text { Yanovsky } \\
(\mathrm{H})\end{array}$ & 0.1 & 0.5 & 1.6 & 2.2 & 7.1 & 8.8 & 9.8 \\
\hline $\begin{array}{l}\text { Cooling P. } \\
(\mathrm{H})\end{array}$ & 0.2 & 0.5 & 0.1 & 0.0 & 7.3 & 7.6 & 7.9 \\
\hline Svyatoye (M) & 0.1 & 1.1 & & & 0.7 & 0.8 & 1.7 \\
\hline $\begin{array}{l}\text { Stoyacheye } \\
\text { (L) }\end{array}$ & nd & 0.0 & & & 0.1 & 0.1 & 0.1 \\
\hline Dvoriche (L) & 0.0 & 0.0 & & & 0.0 & 0.1 & 0.1 \\
\hline Gorova (L) & 0.0 & 0.0 & & & 0.0 & 0.0 & 0.0 \\
\hline
\end{tabular}

$(\mathrm{H}))$ to 8.4 (Glubokoye $(\mathrm{H})) \mu \mathrm{Gy} / \mathrm{h}$ in perch (Table 1 ). The ${ }^{137}$ Cs internal dose rates ranged from 0 (Gorova (L), Dvoriche (L), and Stoyacheye (L)) to 0.5 and 1.4 (Glubokoye $(\mathrm{H})$ ) $\mu \mathrm{Gy} / \mathrm{h}$ in roach and perch, respectively. The highest ${ }^{137} \mathrm{Cs}$ external dose rates to fish were calculated in lakes from the CEZ and varied from $5.9 \mu \mathrm{Gy} / \mathrm{h}$ in Glubokoye $(\mathrm{H})$ to 7.3 $\mu \mathrm{Gy} / \mathrm{h}$ in Cooling Pond $(\mathrm{H})$ (Table 1$)$. The external dose to fish from Svyatoye $(\mathrm{M})$ was 10 times lower $(0.7 \mu \mathrm{Gy} / \mathrm{h})$. The external doses were very low for the three other lakes (L). The total $\beta$ and $\gamma$ dose rate ranged from $7.6 \mu \mathrm{Gy} / \mathrm{h}$ in roach from Cooling Pond $(\mathrm{H})$ to $15.7 \mu \mathrm{Gy} / \mathrm{h}$ in perch from Glubokoye (H) Lake. The total $\alpha$ dose rate in perch and roach ranged from 0.11 to 0.24 and from 0.01 to $0.02 \mu \mathrm{Gy} / \mathrm{h}$ in the liver and muscle, respectively (Table 2 ). The ${ }^{241} \mathrm{Am}$ internal dose rate contributes to $63 \%$ and $87 \%$ of the total $\alpha$ dose rate in liver and muscle of fish, respectively. The ${ }^{239,240} \mathrm{Pu}$ internal dose rate contributes to $27 \%$ and $10 \%$ of the total $\alpha$ dose rate in liver and muscle of fish, respectively. The ${ }^{238} \mathrm{Pu}$ internal dose rate contributes to $10 \%$ and $4 \%$ of the total $\alpha$ dose rate in liver and muscle of fish, respectively. The total $\alpha$ dose rate contributes to $1.2-1.9 \%$ of the total $(\alpha, \beta$, and $\gamma)$ dose rate in fish from the three highly contaminated lakes.
Fish Species Abundance. The relative abundance of fish species does not differ between lakes $(p=0.59)$ therefore there is no evidence of negative effects of radiation exposure on fish biodiversity (Figure S2).

General Health Condition. The lengths of the fish were not significantly different across lakes $(p=0.85)$ (Table S4). The body weights of perch from the different lakes did not differ, except for Svyatoye (M), where the values recorded were significantly higher. The weights of the roach from Glubokoye $(\mathrm{H})$ and Svyatoye $(\mathrm{M})$ were the highest and there was no difference between Yanovsky $(\mathrm{H})$, Cooling Pond $(\mathrm{H})$, and Gorova (L). The Fulton condition (FC) index of roach from the different lakes did not significantly vary $(p=0.99)$. The FC of the perch from Cooling Pond $(\mathrm{H})$, Yanovsky $(\mathrm{H})$, and Glubokoye $(\mathrm{H})$ were smaller than for perch from Stoyacheye $(\mathrm{L})(p<0.01)$ but were similar to the FC of the perch from Svyatoye (L), Dvoriche (L), and Gorova (L) (Table S5). The hepatosomatic index (HSI) of perch did not significantly vary across sites $(p=0.5)$. The HSI of roach from Glubokoye $(\mathrm{H})$, Yanovsky $(\mathrm{H})$, and Cooling Pond $(\mathrm{H})$ were significantly higher than for roach from Svyatoye $(\mathrm{M})(p<$ 0.05 ) but were similar to the HSI of the roach from Dvoriche (L) (Table S5). No disease nor gross tumors or malformations were recorded in any of the fish collected. Parasites were observed in liver of the perch from Yanovsky $(\mathrm{H})$, Gorova $(\mathrm{L})$, Stoyacheye (L), and Dvoriche (L) and the prevalence was $55 \%, 6 \%, 31 \%$, and $14 \%$, respectively. The histological analyses of the liver did not reveal any pretumor (Foci of cellular alterations) and tumor (Hepatocellular adenoma and carcinoma) lesions nor more lesions associated with nuclear and cellular polymorphism, cell death, inflammation, regeneration, and melano-macrophage centers in exposed fish.

Reproductive Status. The gonadosomatic index (GSI) of perch and roach were significantly lower at Yanovsky $(\mathrm{H})$ and Cooling Pond $(\mathrm{H})$ than at Dvoriche $(\mathrm{L})$ and Gorova $(\mathrm{L})(p<$ 0.05 ) (Figure S3). The GSI of perch from Glubokoye $(\mathrm{H})$ was significantly lower than perch from Gorova $(\mathrm{L})(p=0.0004)$ (Figure 2A). No significant difference was found among the GSI of perch from Glubokoye $(\mathrm{H})$, Yanosvsky $(\mathrm{H})$, Cooling Pond $(\mathrm{H})$, Svyatoye $(\mathrm{M})$ and Stoyacheye $(\mathrm{L})(p>0.05)$ (Figure S3A). No significant difference was found among the GSI of roach from Glubokoye $(\mathrm{H})$, Dvoriche $(\mathrm{L})$, and Gorova (L) $(p>0.05)$ (Figure S3B). The fish age did not significantly influence the GSI of roach $(p=0.11)$ and perch $(p=0.15)$.

The GSI of perch was inversely correlated to the percentage of immature oocytes in Yanovsky $(\mathrm{H})$ (cor: $-0.85, p<0.001)$, Cooling Pond $(\mathrm{H})$ (cor: $-0.77, p<0.001$ ) and Glubokoye $(\mathrm{H})$ (cor: $-0.66, p=0.0008$ ) but not in Gorova (L) (cor: $-0.28, p=0.30)$, Dvoriche (L) (cor: 0.12, $p=0.80$ ), Stoyacheye (L) (cor: $-0.24, p=0.44)$ and Svyatoye $(\mathrm{M})$ (cor: $-0.37, p=0.16)$. The correlation was significant in Cooling Pond $(\mathrm{H})$ and Yanovsky $(\mathrm{H})$ due to the presence of sexually

Table 2. Table Showing the Calculated ${ }^{241} \mathrm{Am},{ }^{238} \mathrm{Pu}$, and ${ }^{239,240} \mathrm{Pu}$ Internal Dose Rates

\begin{tabular}{|c|c|c|c|c|c|c|c|c|}
\hline \multirow[b]{3}{*}{ lake $(\mathrm{H})$} & \multicolumn{4}{|c|}{$\begin{array}{l}{ }^{241} \mathrm{Am} \text { internal dose rate }(\mu \mathrm{Gy} / \mathrm{h}) \\
2015\end{array}$} & \multicolumn{4}{|c|}{$\begin{array}{c}{ }^{239,240} \mathrm{Pu} \text { internal dose rate }(\mu \mathrm{Gy} / \mathrm{h}) \\
2015\end{array}$} \\
\hline & \multicolumn{2}{|c|}{ roach } & \multicolumn{2}{|c|}{ perch } & \multicolumn{2}{|c|}{ roach } & \multicolumn{2}{|c|}{ perch } \\
\hline & liver & muscle & liver & muscle & liver & muscle & liver & muscle \\
\hline Glubokoye & 0.10 & 0.01 & 0 . & 0.01 & 0.05 & 0.01 & 0.07 & 0.0040 \\
\hline Yanovsky & 0.11 & 0.01 & 0.07 & 0.01 & 0.04 & 0.0003 & 0.03 & 0.0002 \\
\hline Cooling P. & 0.08 & 0.01 & 0.07 & 0.01 & 0.03 & 0.0002 & 0.03 & 0.0003 \\
\hline
\end{tabular}

total $\alpha$ internal dose rate $(\mu \mathrm{Gy} / \mathrm{h})$

\begin{tabular}{ccccc}
${ }^{238} \mathrm{Pu}$ internal dose rate $(\mu \mathrm{Gy} / \mathrm{h})$ & 2015 \\
\cline { 1 - 1 } \cline { 5 - 6 } \cline { 5 - 6 } liver & muscle & & liver & muscle \\
0.02 & 0.002 & & 0.03 & 0.002 \\
0.01 & 0.0001 & & 0.01 & 0.0001
\end{tabular}

.

\begin{tabular}{ccccc}
\multicolumn{4}{c}{2015} \\
\multicolumn{2}{c}{ roach } & & \multicolumn{2}{c}{ perch } \\
\cline { 1 - 1 } \cline { 5 - 6 } liver & muscle & & liver & muscle \\
0.16 & 0.02 & & 0.24 & 0.02 \\
0.16 & 0.01 & & 0.11 & 0.01 \\
0.12 & 0.01 & & 0.11 & 0.01
\end{tabular}


immature fish displaying lower GSI than maturing fish $(p<$ $0.001) ; 30 \%$ and $45 \%$ of female perch had gonads containing only immature oocytes in Cooling Pond $(\mathrm{H})$ and Yanovsky (H) lake $(p<0.001)$ in September (Figure 3A,B). This
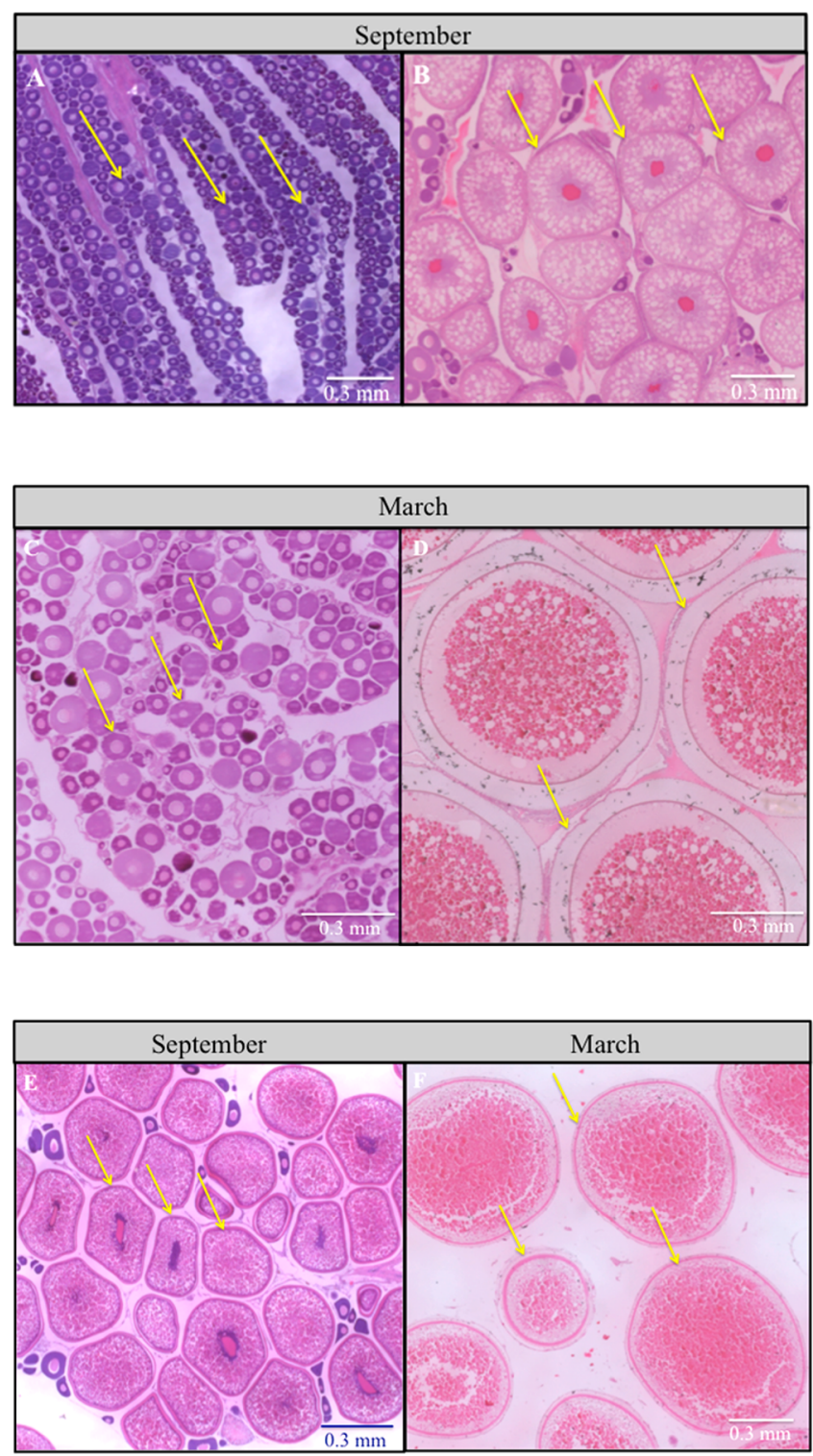

Figure 3. Pictures of tissue sections showing oocytes of female perch $(\mathrm{A}, \mathrm{B}, \mathrm{C}$, and $\mathrm{D})$ and roach $(\mathrm{E}, \mathrm{F})$. (A and C) perinuclear oocytes (immature) from perch collected in September and March; (B and E) corticular alveolar oocytes (maturing) from perch and roach, respectively, collected in September; (D and F) vitellogenic oocytes (mature) from perch and roach, respectively, collected in March.

phenotype was still found in Yanovsky $(\mathrm{H})$ (38\%) and Cooling Pond $(\mathrm{H})(25 \%)$ before spawning time in March (Figure 3C) when oocytes should have been mature in all fish (Figure $3 \mathrm{D}, \mathrm{F})$. The occurrence of the immature phenotype was positively correlated with the ${ }^{137} \mathrm{Cs}$ external dose rate (cor: 0.78; $p=0.04$ ) but not to the ${ }^{90} \mathrm{Sr}$ internal (cor: $-0.04 ; p=$ 0.9 ) or the total (cor: $0.43 ; p=0.3$ ) dose rates. All the female roach collected were maturing in September and mature in March (Figure 3E,F). The GSI of roach was inversely correlated to the percentage of immature oocytes in Glubokoye $(\mathrm{H})$ (cor: $-0.59, p=0.02$ ), Yanovsky $(\mathrm{H})$ (cor:
$-0.67, p=0.0008$ ), Cooling Pond $(\mathrm{H})$ (cor: -0.52 , only 3 observations), Gorova (L) (cor: $-0.68, p=0.003$ ) but not in Svyatoye (M) (cor: $-0.32, p=0.4$ ) and Dvoriche (L) (cor: $-0.19, p=0.5)$. The age did not influence the percentage of immature oocytes in perch $(p=0.19)$ and roach $(p=0.86)$.

Exposed Maturing Perch Gonads Contain a Higher Proportion of Immature Oocytes. The immature fish (100\% of immature oocytes) were not included in these analyses. Maturing female perch gonads from Glubokoye $(\mathrm{H})$ contained a higher percentage of immature oocytes (68\%) than fish from Cooling Pond $(\mathrm{H})(61 \%, p=0.03)$, Svyatoye (M) (58\%, $p=0.046)$, Stoyacheye (L) (57\%, $p=0.0006)$, Dvoriche (L) $(58 \%, p=0.03)$, and Gorova (L) $(54 \%, p=$ 0.00008) (Figure 4A). Female perch gonads from Yanovsky

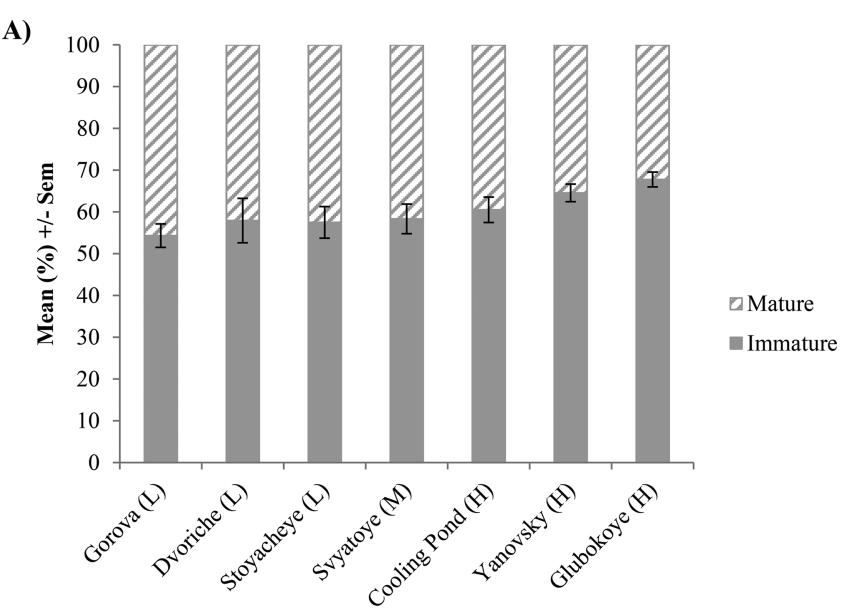

B)

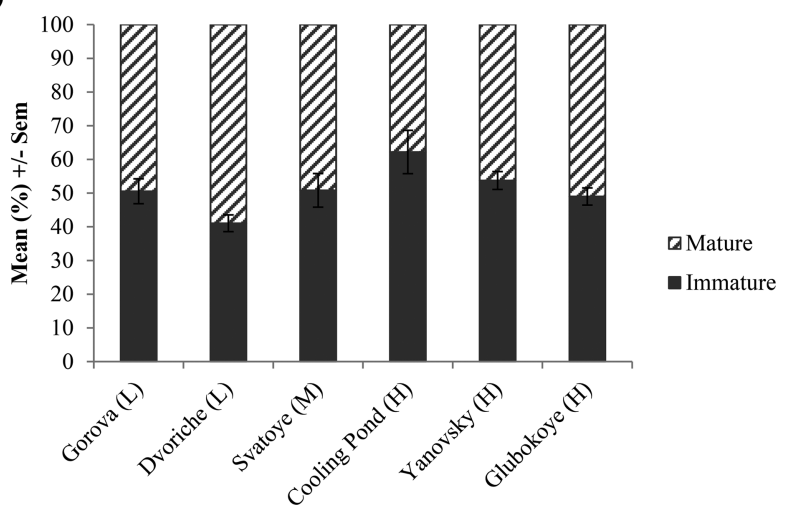

Figure 4. Distribution of immature and mature oocytes in maturing female perch (A) and roach (B) gonads collected in the different lakes. The sexually immature perch (only containing perinuclear oocytes) were not considered.

$(\mathrm{H})(65 \%)$ contained a higher percentage of immature oocytes than fish from Stoyacheye $(\mathrm{L})(p=0.03)$ and Gorova $(\mathrm{L})(p=$ 0.01) (Figure 4A). Female perch gonads from Cooling Pond $(\mathrm{H})$ contain a similar percentage of immature oocytes than fish from the other lakes $(p>0.05)$ except for fish from Glubokoye $(\mathrm{H})$ (Figure $4 \mathrm{~A})$. The percentage of immature oocytes was positively correlated to the total (cor: $0.92, p=0.004),{ }^{90} \mathrm{Sr}$ internal (cor: 0.78, $p=0.04$ ), and ${ }^{137} \mathrm{Cs}$ external (cor: 0.78, $p=$ $0.04)$ dose rates.

Variable Proportion of Immature Oocytes in Roach Gonads Across Lakes. Roach from Cooling Pond $(\mathrm{H})$ and 
Yanovsky $(\mathrm{H})$ had a higher proportion of immature eggs (62\% and $54 \%$ respectively) than roach from Dvoriche (L) Lake $(41 \%)(p<0.01)$ but displayed a similar proportion of immature eggs as roach from lake Gorova (L) (51\%) and Svyatoye (M) (51\%) ( $p>0.05)$ (Figure 4B). Roach from Glubokoye (H) (49\%) Lake displayed a similar proportion of immature eggs as roach from Dvoriche (L) (41\%), Gorova (L) $(51 \%)$ and Svyatoye (M) (51\%) lakes $(p>0.05)$ (Figure 4B).

The female perch, roach gonads, and oocytes did not display any structural damage.

No Chromosomal Damage Was Evidenced in Blood Cells of Exposed Fish. The number of micronuclei did not significantly vary across the sites for both species $(p=0.14>$ 0.05) (Table S6).

\section{DISCUSSION}

Physico-chemical values correspond to good quality waters according to the European surface water quality standards (OECD, Annex1), and nutrient concentrations are typical of oligotrophic waters (nitrate $<1-3 \mathrm{mg} / \mathrm{L}$; phosphate $<0.04 \mathrm{mg}$ / L, OECD, Annex1).

${ }^{137} \mathrm{Cs},{ }^{90} \mathrm{Sr},{ }^{241} \mathrm{Am},{ }^{239,240} \mathrm{Pu}$, and ${ }^{238} \mathrm{Pu}$ Specific Activities. Thirty years after the accident, the activity concentration of ${ }^{137} \mathrm{Cs}$ and ${ }^{90} \mathrm{Sr}$ are still higher than the EU $\left(1250 \mathrm{~Bq} / \mathrm{kg}\right.$ for ${ }^{137} \mathrm{Cs} ; 750 \mathrm{~Bq} / \mathrm{kg}$ for $\left.{ }^{90} \mathrm{Sr}\right)$, Ukrainian $(150$ $\mathrm{Bq} / \mathrm{kg}$ for ${ }^{137} \mathrm{Cs} ; 35 \mathrm{~Bq} / \mathrm{kg}$ for $\left.{ }^{90} \mathrm{Sr}\right)$, and Japanese $(100 \mathrm{~Bq} / \mathrm{kg})$ maximum permissible level for human consumption in some of the lakes affected by the Chernobyl nuclear accident (see SI for details).

Activity concentrations of ${ }^{137} \mathrm{Cs}$ measured in perch from Glubokoye (H) and Svyatoye (M) lakes were the highest and reach 7844 and $6090 \mathrm{~Bq} / \mathrm{kg}$, respectively. For Svyatoye (M), which is the most distant of the seven lakes, the high values are due to the high initial amount of ${ }^{137} \mathrm{Cs}$ deposited in this area, as well as hydrology and hydrochemistry of the water body. This is a closed lake with a very low water exchange rate and low natural potassium concentration, which explains the slow decontamination. $^{10,22}$

The most important pathway of ${ }^{137} \mathrm{Cs}$ accumulation in fish is through the diet route. ${ }^{23,24}$ The results evidenced a ${ }^{137} \mathrm{Cs}$ biomagnification phenomenon. As a carnivorous fish, the perch significantly accumulates $2-3$ times more ${ }^{137} \mathrm{Cs}$ than its omnivorous prey, the roach. This is consistent with previous studies led on perch and nonpredatory fish from Chernobyl lakes where the ${ }^{137} \mathrm{Cs}$ contamination levels exceeded that of nonpredatory ones by 2 in smaller fish ${ }^{22}$ or 3-10 times in larger. $^{12}$

Activity concentrations of ${ }^{90} \mathrm{Sr}$ were the highest in perch and roach from Glubokoye Lake $(\mathrm{H})$ reaching a mean of 13636 and $12556 \mathrm{~Bq} / \mathrm{kg}$, decreased significantly in fish from Yanovsky $(\mathrm{H})$, and were the lowest in fish from Cooling Pond $(\mathrm{H})$. The difference of activity concentrations between sites might be due to the heterogeneous deposition of burning particles just after the Chernobyl NPP accident. ${ }^{9}$ The results show that, contrary to ${ }^{137} \mathrm{Cs},{ }^{90} \mathrm{Sr}$ is not biomagnified between roach and perch. ${ }^{90} \mathrm{Sr}$ can be accumulated from the water via the gills ${ }^{25}$ or through the diet. ${ }^{26}$

Activity concentrations of ${ }^{241} \mathrm{Am},{ }^{239,240} \mathrm{Pu}$, and ${ }^{238} \mathrm{Pu}$ were higher in liver than in muscle of both fish species and the liver of perch from Glubokoye $(\mathrm{H})$ lake contained at least 2 times more ${ }^{241} \mathrm{Am},{ }^{239,240} \mathrm{Pu}$, and ${ }^{238} \mathrm{Pu}(44,23$, and $8 \mathrm{~Bq} / \mathrm{kg}$ w.w., respectively) than perch from Yanovsky $(\mathrm{H})$ and Cooling Pond $(\mathrm{H})$. No biomagnification of transuranium radioisotopes were evidenced between roach and perch. These results corroborate previous findings from environmental studies on fish from the Baltic sea. ${ }^{27}$ The dietary route was suggested to play a major role in the plutonium intake in fish. At Chernobyl, the bioavailability of plutonium isotopes varies depending on the association with fuel particles.

Doses Span the Lowest Protection Level for an Ecosystem. The estimation of the radiation dose is discussed in the Supporting Information. In the present study, the total dose rate to roach and perch from the CEZ lakes was estimated to range from 7.6 to $14.1 \mu \mathrm{Gy} / \mathrm{h}$ and from 7.9 to $15.7 \mu \mathrm{Gy} / \mathrm{h}$, respectively. The dose rate in fish from Glubokoye $(\mathrm{H})$ lake was the highest especially due to the contribution of the high ${ }^{90} \mathrm{Sr}$ internal dose rate $(7.7$ and $8.4 \mu \mathrm{Gy} / \mathrm{h}$ for roach and perch, respectively). However, as a $\beta$ emitter and mainly accumulated in calcium-rich tissues, a higher dose is expected in near bone tissues than in other tissues, more than a few millimeters distant. The total internal $\alpha$ dose rate was estimated to range from 0.01 to $0.2 \mu \mathrm{Gy} / \mathrm{h}$ in perch and roach which is approximately 2 orders of magnitude below the total $\beta$ and $\gamma$ total dose rate, although the relative biological effectiveness of the $\alpha$ dose is considered an order of magnitude higher. The doses observed in the study lakes span the recommended screening level for protection of an ecosystem of $10 \mu \mathrm{Gy} / \mathrm{h}$ $\left(\right.$ ERICA project $\left.{ }^{20}\right)$. Although we have observed subtle effects of radiation on the reproduction of perch at dose rates below relevant reference levels $(40-400 \mu \mathrm{Gy} / \mathrm{h}){ }^{28}$ no clear evidence of population level effects was evidenced. Reference levels are usually set to protect populations of species; therefore, this study does not contradict currently accepted levels.

No Effect on the Relative Abundance of Fish Species. In the present study, the relative abundance of fish species did not vary across the sites, suggesting no negative effect of radiation on fish biodiversity, though absolute population densities were not studied. The lack of observed effect on species diversity is in agreement with previous studies on aquatic macroinvertebrate and mammal populations ${ }^{2,3}$ which showed high diversity (and abundance) in the Chernobyl affected areas. Other studies, however, have found reduced abundance of insect, spider, and mammal populations. ${ }^{4-6}$ Our results show that 30 years after the accident, the fish population is in good general health. This is in accordance with the lowest protection level for an ecosystem of $10 \mu \mathrm{Gy} / \mathrm{h}$ (ERICA project ${ }^{20}$ ) and the benchmark levels established for reference pelagic fish species $(40-400 \mu \mathrm{Gy} / \mathrm{h}){ }^{29}$ At the individual level, the absence of significant variation of the Fulton condition and hepatosomatic index further supports the previous finding at the population level by showing that exposure to radiation has not affected the general health and energetic status of fish. Finally, no genotoxic effect was evidenced as previously described in a previous study on catfish from Cooling Pond $(\mathrm{H}){ }^{17}$

Potential Effect of Radiation on the Reproductive Biology of Exposed Fish. Previous studies on fish from Cooling Pond $(\mathrm{H})$ of the Chernobyl NPP have reported negative effects of radiation on the reproductive system (sterility and anomalies of gonads) at a dose rate above 83$208 \mu \mathrm{Gy} / \mathrm{h} .{ }^{30}$ Severe anomalies of the reproductive system of fish exposed to radiation have been described in carp (asymmetry, sterility, abnormal cells or absence of gonads) collected several years after the Kyshtym $(21 \mu \mathrm{Gy} / \mathrm{h}$ in $1972-$ 1975 ) and the Chernobyl (17 $\mu \mathrm{Gy} / \mathrm{h}$ in 1989-1992) accidents. Such abnormalities were also identified in the 
offspring of carp from the Chernobyl NPP Cooling Pond $(\mathrm{H})$ born in 1989 and they were less pronounced in the offspring born in $1990 .^{7}$ Gonad abnormalities have also been recorded in postaccident generations $\left(\mathrm{F}_{2}-\mathrm{F}_{4}\right)$ of perch (sterilization process of male, destruction of oocytes) and roach (sterilization process of female, destruction and resorption of oocytes, degenerations, abnormal morphology) from Cooling Pond and Glubokoye lake ${ }^{13}$ although the number of fish sampled in that study was too low to draw a robust conclusion (4 and 9 specimens in Glubokoye for perch and roach respectively in 2004). In our study, the gonads and oocytes did not display any of those abnormalities, highlighting overall a better reproductive condition of the perch and roach population, 30 years after the accident.

However, the results of this study provide evidence of two types of inhibitory effects on the reproductive biology of exposed female perch: the suppression of gonad development and a delay in the recruitment of mature oocytes. These effects can result from both the toxic action mode of radionuclides and the capacity of the population to adapt to contamination pressure.

The suppression of gonad development in fish is the result of long-term exposure to stress. Although no differences were detected in mean gonadosomatic index (GSI) of female perch between the lakes, the lowest GSI values observed in perch from Yanovsky $(\mathrm{H})$ and Cooling Pond $(\mathrm{H})$ are due to the presence of $45 \%$ and $30 \%$ sexually immature females, respectively. Such phenotypes were not found in roach. This phenotype, however, was not found in fish from Glubokoye $(\mathrm{H})$ that are absorbing the highest total and internal ${ }^{90} \mathrm{Sr}$ dose rate. The occurrence of this phenotype was only correlated to the ${ }^{137} \mathrm{Cs}$ external dose rate $(p<0.05)$. Thus, the interpretation of observed inhibition of gonad development in perch from Yanovsky lake $(\mathrm{H})$ and Cooling Pond $(\mathrm{H})$ might be confounded by other factors, including food availability and social interactions since the phenotype was not observed at the equally contaminated Glubokoye lake $(\mathrm{H})$. It is possible that higher selective pressure due to the ecology of the lake (such as a more highly competitive ecosystem) may have encouraged the more rapid disappearance of this disadvantageous phenotype over the several generations that have passed since the accident. To our knowledge, studies showing undeveloped phenotypes of fish gonads exposed to radiation are scarce. One study in the literature found that $30 \%$ of female Mozambique tilapia waterborne exposed during their whole life to a dose of $1.3 \times 10^{3}$ to $1.7 \times 10^{3} \mu \mathrm{Gy} / \mathrm{h}$ of ${ }^{90} \mathrm{Sr}$ under laboratory conditions had underdeveloped ovaries. ${ }^{7}$ This dose rate is, however, approximately 50-100 times higher than current dose rates to fish at Chernobyl.

The maturing female perch from Glubokoye $(\mathrm{H})$ (15.7 $\mu \mathrm{Gy} / \mathrm{h})$ and Yanovsky $(\mathrm{H})(9.8 \mu \mathrm{Gy} / \mathrm{h})$ lakes contained a higher proportion of immature oocytes (68\% and $65 \%$ respectively) than perch from all other lakes. This is strongly correlated to the higher dose rate $(p<0.05)$. The perch containing a higher percentage of immature oocytes had a lower GSI in Yanovsky $(\mathrm{H})$, Cooling Pond $(\mathrm{H})$, and Glubokoye $(\mathrm{H})(p<0.001)$. Therefore, long-term exposure to radiation was found to affect the maturation of oocytes and especially the recruitment of cortical alveolar oocytes in fish absorbing the highest total dose rates. In the literature, a 2 weeks delay in spawning has been described in the Siberian roach exposed to a dose rate of $83-333 \mu \mathrm{Gy} / \mathrm{h}, 15-20$ years after the acute contamination event of the Kyshtym accident
(Mayak Production Association), Southern Ural. ${ }^{7}$ Moreover, UNSCEAR reported a delay in spawning in fish exposed to very high dose rates of $500-1000 \mu \mathrm{Gy} / \mathrm{h}^{31}$ In the present study, the inhibitory effect on oocyte development was no longer observed in the March sampling period, just before spawning, as all oocytes were mature. Therefore, the disruptions to oocyte development observed in the three most contaminated lakes will not necessarily lead to population-level effects. No disruption of the reproductive status of female roach gonads was observed. The mechanisms by which radionuclides could exert an effect on the endocrine system and subsequently alter the gonad maturation of fish are unknown. The present study shows that exposure to radionuclides affects oogenesis in the wild perch population. Further research on the molecular mechanisms involved is in progress.

The evidence presented here strongly suggests that 30 years after the Chernobyl accident, the reproductive status of perch is affected by chronic, low level radiation in their natural environment. A clear increase was observed in proportion of immature oocytes from $54 \%$ in fish from the reference lakes to $68 \%$ in fish from the highly contaminated lake $(15.7 \mu \mathrm{Gy} / \mathrm{h})$. Evidence for a high proportion of fish with undeveloped gonads was found in two of the most contaminated lakes, but not in the third similarly contaminated lake meaning that the effect could not unambiguously be attributed to past or current radiation. It is unknown whether effects observed here are due to three decades of multigenerational (direct) exposure to radiation and/or to trans-generational effects linked to the past history of contamination. In Cooling Pond, dose rates to fish in the short term after the accident reached $400 \mu \mathrm{Gy} / \mathrm{h}$ and external sediment dose rates reached $4000 \mu \mathrm{Gy} / \mathrm{h} .{ }^{32}$ The early high dose rates are of crucial importance because, as a result of trans-generational exposure, the current dose might not be directly related to the effects observed but might rather be a result of previous higher exposure history.

The present study uniquely assesses the effect on fish health of a wide range of environmental radiation exposure levels from highly contaminated lakes within the $10 \mathrm{~km}$ Chernobyl exclusion zone in Ukraine to lakes with dose rates close to natural background. This study of multiple biological parameters, has shown that the populations of two species are generally in good physiological (including reproductive) health, but that there is evidence that a proportion of the female perch population has either a failure or delay in maturation of the gonads. It cannot be determined whether this is an effect of ongoing chronic low dose radiation or an effect of higher dose rates on previous generations. The present study does not indicate significant radiation effects on fish at the population level. It is important to note that fish have high fecundity; for example, each female perch can produce thousands of eggs per year. ${ }^{33}$ Thus, although some effects on perch reproduction have been observed, it seems unlikely that these effects would significantly impact fish population density.

\section{ASSOCIATED CONTENT}

\section{S Supporting Information}

The Supporting Information is available free of charge on the ACS Publications website at DOI: 10.1021/acs.est.8b02378.

Further details of the methods, results and discussion sections, Figures S1-S3 and Tables S1-S6 (PDF) 


\section{AUTHOR INFORMATION}

\section{Corresponding Author}

*Phone: +353 (0)9174 2516; e-mail: ade.lerebours@hotmail.

fr.

\section{ORCID $\odot$}

Adélaïde Lerebours: 0000-0001-9789-7704

Jim T. Smith: 0000-0002-0808-2739

Notes

The authors declare no competing financial interest.

\section{ACKNOWLEDGMENTS}

Authors are grateful to L Bogdan, C Sharpe, Vladislav, A Zubey, M Devonshire, and N Fuller. This work was completed as part of the TREE (Transfer-Exposure-Effects) consortium under the RATE programme (Radioactivity and the Environment), funded by the Environment Agency and Radioactive Waste Management Ltd (NERC grant NE/L000393/1).

\section{REFERENCES}

(1) Real, A.; Sundell-Bergman, S.; Knowles, J. F.; Woodhead, D. S.; Zinger, I. Effects of Ionising Radiation Exposure on Plants, Fish and Mammals: Relevant Data for Environmental Radiation Protection. J. Radiol. Prot. 2004, 24 (4A), A123-A137.

(2) Murphy, J. F.; Nagorskaya, L. L.; Smith, J. T. Abundance and Diversity of Aquatic Macroinvertebrate Communities in lakes Exposed to Chernobyl-Derived Ionising Radiation. J. Environ. Radioact. 2011, 102 (7), 688-694.

(3) Deryabina, T. G.; Kuchmel, S. V.; Nagorskaya, L. L.; Hinton, T. G.; Beasley, J. C.; Lerebours, A.; Smith, J. T. Long-Term Census Data Reveal Abundant Wildlife Populations at Chernobyl. Curr. Biol. 2015, 25 (19), R824-R826.

(4) Møller, A. P.; Mousseau, T. A. Species Richness and Abundance of Forest Birds in Relation to Radiation at Chernobyl. Biol. Lett. 2007, 3 (5), 483-486.

(5) Moller, A. P.; Mousseau, T. A. Reduced Abundance of Insects and Spiders Linked to Radiation at Chernobyl 20 Years after the Accident. Biol. Lett. 2009, 5 (3), 356-359.

(6) Møller, A. P.; Mousseau, T. A. Assessing Effects of Radiation on Abundance of Mammals and Predator-Prey Interactions in Chernobyl Using Tracks in the Snow. Ecol. Indic. 2013, 26, 112-116.

(7) Sazykina, T. G.; Kryshev, A. I. EPIC Database on the Effects of Chronic Radiation in Fish: Russian/FSU Data. J. Environ. Radioact. 2003, 68 (1), 65-87.

(8) Kryshev, A. I. Modelling the Accidental Radioactive Contamination and Assessment of Doses to Biota in the Chernobyl NPP's Cooling Pond. Proceedings of the topical meeting of International Union of Radioecologists 1998, No. mol 1, pp 32-38.

(9) Chernobyl-Catastrophe and Consequences; Springer-Praxis Books in Environmental Sciences; Smith, J. T., Beresford, N. A., Eds.; Springer: Berlin, 2005.

(10) Ryabov, I. N. Long-Term Observation of Radioactivity Contamination in Fish around Chernobyl 2002, 11, 112-122.

(11) Koulikov, A. O.; Ryabov, I. N. Specific Cesium Activity in Freshwater Fish and the Size Effect. Sci. Total Environ. 1992, 112 (1), $125-142$.

(12) Kryshev, I. I. J. Environ. Radioact. 1995, 27 (3), 207-219.

(13) Belova, N. V.; Emel'yanova, N. G.; Makeeva, A. P.; Ryabov, I. N. The State of the Reproductive System of Several Fish Species from Water Bodies Polluted with Radionuclides during the Chernobyl Catastrophe. J. Ichthyol. 2007, 47 (5), 366-384.

(14) Belova, N. V.; Emel'yanova, N. G. Status of the Reproductive System of Bony Fish from the Teterev River and the Kiev Reservoir 20 Years after the Chernobyl Accident. J. Ichthyol. 2009, 49 (9), 793802.

(15) Belova, N. V. Radiobiological Analysis of Silver Carp Hypophthalm Ichthys Molitrix in the Water Cooler of the Chernobyl
Nuclear Power Plant in the Post Emergency Period. 1. The State of the Reproductive System in Fish That Were Exposed to the Emergency. Vopr. Ikhtiol 1993, 33 (6), 814-828.

(16) Suzuki, Y. Influences of Radiation on Carp from Farm Ponds in Fukushima. J. Radiat. Res. 2015, 56 (suppl 1), i19-i23.

(17) Sugg, D. W.; Bickham, J. W.; Brooks, J. A.; Lomakin, M. D.; Jagoe, C. H.; Dallas, C. E.; Smith, M. H.; Baker, R. J.; Chesser, R. K. DNA Damage and Radiocesium in Channel Catfish from Chernobyl. Environ. Toxicol. Chem. 1996, 15 (7), 1057-1063.

(18) Hollands, C. The Animal (Scientific Procedure) Act 1986. Lancet 1986, 328 (8497), 32.

(19) Biological Effects of Contaminants: Use of Liver Pathology of the European Flatfish Dab (Limanda Limanda L.) and Flounder (Platichthys Flesus L.) for Monitoring. ICES Techniques in Marine Environmental Sciences; Feist, S. W., Ed.; International Council for the Exploration of the Sea: Copenhagen, 2004.

(20) Brown, J. E.; Alfonso, B.; Avila, R.; Beresford, N. A.; Copplestone, D.; Hosseini, A. A New Version of the ERICA Tool to Facilitate Impact Assessments of Radioactivity on Wild Plants and Animals. J. Environ. Radioact. 2016, 153, 141-148.

(21) Smith, J. T.; Sasina, N. V.; Kryshev, A. I.; Belova, N. V.; Kudelsky, A. V. A Review and Test of Predictive Models for the Bioaccumulation of Radiostrontium in Fish. J. Environ. Radioact. 2009, 100 (11), 950-954.

(22) Smith, J. T.; Kudelsky, A. V.; Ryabov, I. N.; Hadderingh, R. H. Radiocaesium Concentration Factors of Chernobyl-Contaminated Fish: A Study of the Influence of Potassium, and "Blind" Testing of a Previously Developed Model. J. Environ. Radioact. 2000, 48, 359-369.

(23) Forseth, T.; Ugedal, O.; Jonsson, B.; Langeland, A.; Njastad, O. Radiocaesium Turnover in Arctic Charr (Salvelinus Alpinus) and Brown Trout (Salmo Trutta) in a Norwegian Lake. J. Appl. Ecol. 1991, 28 (3), 1053.

(24) Elliott, J. M.; Hilton, J.; Rigg, E.; Tullett, P. A.; Swift, D. J.; Leonard, D. R. P. Sources of Variation in Post-Chernobyl Radiocaesium in Fish from Two Cumbrian lakes (North-West England). J. Appl. Ecol. 1992, 29 (1), 108.

(25) Chowdhury, M. J.; Blust, R. A Mechanistic Model for the Uptake of Waterborne Strontium in the Common Carp (Cyprinus Carpio L.). Environ. Sci. Technol. 2001, 35 (4), 669-675.

(26) Kryshev, A. I. Model Reconstruction of 90Sr Concentrations in Fish from 16 Ural lakes Contaminated by the Kyshtym Accident of 1957. J. Environ. Radioact. 2002, 64 (1), 67-84.

(27) Skwarzec, B.; Struminska, D. I.; Borylo, A. Bioaccumulation and Distribution of Plutonium in Fish from Gdansk Bay. J. Environ. Radioact. 2001, 55 (2), 167-178.

(28) Environmental Protection-the Concept and Use of Reference Animals and Plants. Ann. ICRP 2008, 108, 4-6.

(29) Larsson, C. M. An Overview of the ERICA Integrated Approach to the Assessment and Management of Environmental Risks from Ionising Contaminants. J. Environ. Radioact. 2008, 99 (9), 1364-1370.

(30) Kryshev, A. I.; Sazykina, T. G. Comparative Analysis of Doses to Aquatic Biota in Water Bodies Impacted by Radioactive Contamination. J. Environ. Radioact. 2012, 108, 9-14.

(31) Sources and Effects of Ionizing Radiation. UNSCEAR 2008 Report to the General Assembly, with Scientific Indexes; United Nations: New York, 2011; Vol. 2.

(32) Kryshev, I. I.; Sazykina, T. G. Assessment of Radiation Doses to Aquatic Organism's in the Chernobyl Contaminated Area. J. Environ. Radioact. 1995, 28, 91-103.

(33) Craig, J. F. Population Dynamics of Perch, Perca Fluviatilis L. in Slapton Ley, Devon.: I. Trapping Behaviour, Reproduction, Migration, Population Estimates, Mortality and Food. Freshwater Biol. 1974, 4 (5), 417-431. 